\title{
Financial Arrangement Performance of Makassar City Local Council Study of good governance principle in legalizing and executing local council budget
}

\author{
Djainuddin Maggasingang \\ Makassar Islamic University of South Sulawesi Province of Indonesia
}

\begin{abstract}
Institutional reform and public financial management by means of decentralization and or regional autonomy policy has strengthened local council. Regional autonomy policy has given local council the strategic position by having several rights and privileges namely interpellation, inquiry, expressing opinion, protocol, administration and financial rights. Yet, institutional reform has not brought many changes toward the increase of local council performance. The implementation of regional autonomy itself also raises several issues such as
\end{abstract} corruption and budgetary mark-up which involve executive and local council.

Therefore, the objectives of this research are: 1) to analyze the legalizing and executing procedure of Makassar City Local Council in 2010, 2) to analyze the accountability, transparency, responsiveness, effectiveness, and efficiency of Makassar City Local Council performance in legalizing and executing local council budget in 2010, 3) to analyze the influencing factors toward the performance of Makassar City Local Council in legalizing and executing budget, and 4) to propose an alternative performance model of Makassar City Local Council in legalizing and executing budget.

The procedure of legal drafting, legalizing and executing of local council budget in Makassar City has not yet met the administration and legal procedures. It was because of the local council had not made 2009 work plan as the fundamental element for budgetary drafting in 2010; the local council leaders did not directly involved in the regional, local council and procurement budgetary drafting.

The performance accountability of Makassar City Local Council in legalizing and executing local council budget is not yet sufficient for not: a) performing external responsibility report to the people, and b) involving any civilian representatives in drafting, discussing and legalizing local council budget.

The performance transparency of Makassar City local council in legalizing and executing budget is also not sufficient for not: a) publicly published the local council budget to the people and only doing so partially if there is any demand from particular group of people, and b) providing proper media for people to access the information of local council budget.

The performance responsiviness of Makassar City Local Council in legalizing and executing local council budget cannot be classified as responsive enough for their limited effort in encompassing, accommodating, and following up any people's aspiration. The media to encompass and accommodate people's aspiration is not yet prop erly provided.

These lacks of performance had led Makassar City Local Council towards the ineffectiveness and inefficiency in legalizing and executing local council budget and the procurement of goods and services as well as capital expenses.

In order to govern these performance prolems, this article proposed an alternative performance model to increase local council performance especially in implementing good governance principles in executing and executing local council budget through by means of indirect participation mechanism in which people's aspiration can be tunneled through independent institution(s). The independent institution(s) convey people's aspiration to local council and any result or policy produced afterward is conveyed to the people by local council through independent institution(s). By using this alternative model, three pillars of governance namely state, civilians, and private (independent organization), will mutually interact each other. Mechanism of budget determination and utilization will be materialized effectively and efficiently if it is supported by three approaches which are; political approach, administration and management, and legal approach.

Keywords: local council, performance, good governance, budget

\section{Background}

As globalization and democracy issues are getting stronger by the emerging of new perspective in public administration, especially governance, the understanding of public administration should only not be limited to its practice done by executive body, but be broaden to its practice done by both legislative and judicative body which together called as Trias-Politica. In accordance to democracy theory which normatively 
based on slogan "from society, by society, and to society" principle, democratic government should prioritize society interest and avoid any demand on centralization of power and domination of one state institution over another (Widodo, 2001: 99). Trias-politica theory explains that democratic government will be materialized only if three bodies of state power holder (executive, legislative, and yudicative) separate the power. The triaspolitica theory argues that democratic government can only be established if the three body of the state (executive, legislative and judicative) separate their power operationally. The concept of separation of power is the main key to embody the concept of check and balance as one of the democratic government element. This problem is confirmed by Fredrickson (2003:15) which stated that democratic principles can be seen in democratic government when the elected officials (legislative) are able to have controlling function towards appointed officials and and policy implementers (executive). Furthermore, William Niskanen (1971) in Fredrickson (2003: 37) said that to build democratic government which is based on check and balance principle, legislatives role (principal) are significant as a balance control device towards the executive (agent) in democratic government.

Legislative body is a political institution which represents people. This institution has been long functioned as administrative control tool (executive), because people's interests are transformed into action by their choosen representatives. Legislative institution needs to have control over administrative authority given to the bureaucrats (executive) in order to make it run accordingly to the duty and the function. But in the empirically, during the New Order, the power is monopolized by executive. This causes the mechanism of check and balance was not working, especially the unbalance of power and role between legislative body (council and local council) in one hand and between council and government (executive) in another hand (Effendi, 1991). The unfunctionalized of check and balance mechanism had caused some implications in administrative practice. Prior to the late 1990s, the tendency of public service provision and development were strongly rested on government shoulder, rather than society. State intervention and political control had caused bureaucracy as irresponsive, authoritarian, and corrupt. This was responed by the Reform Order government by doing institutional reform and public financial management. Law No. 32/2004 on Local Government and Law No. 33/2004 on Financial Division between Central Government and Local Government were the regulatory reform done by government. These Laws give the opportunity on legislative institutional strengthening in order to put their function and duty back on track.

Local council as the representation of local people has strategic role in conducting local power. It has authorities to legalize regional regulation, local political policy and development, political control over local executive, demanding responsibility as well as interpellation right and non-confidential motion. In order to do their run duty and function, local council members are given privileges regulated in Law No. 32/2004 article 43 and 44. These articles stated that local council has several rights e.g. interpellation, inquiry, expressing opinion, immunity, protocoler, financing, self-defending and administrating rights related to their representative function of the people. Furthermore, in the article 41 was also mentioned that local council has legislized, budgetary, and supervising functions. But in the contrary, institutional reform in terms of regional autonomy does not empower the local council performance. It even led to scandalous matters such as corruption and budgetary mark-up which involved both local council member(s) and local executive(s).

Based on these facts, this article tries to answer some research questions on: 1) how are the mechanism upon legal drafting, legalizing and executing of Makassar City Local Council (MCLC) budget; 2) how is the MCLC performance in the context of accountability, transparency, responsiveness, effectiveness, and efficiency in legalizing and executing budget; 3) What are the contributing and inhibiting factors of MCLC performance in legalizing and executing budget; and 4) What is the alternative performance model of MCLC performance in legalizing and executing budget. These research questions are as of the main purposes of this article.

\section{Research Method}

This research used qualitative inquiry method by attempting to observe a phenomenon or a particular problem deeply in the particular environment context. The phenomenon is MCLC performance in legalizing and executing local council budget for 2010 of budgetary year. The research was conducted in Makassar City of South Sulawesi Province of Indonesia.

Therefore, the main focus of this research are: to describe the mechanism upon legal drafting, legalizing and executing of Makassar City Local Council (MCLC) budget, to describe the MCLC performance in the context of accountability, transparency, responsiveness, effectiveness, and efficiency in legalizing and executing budget, to analyze the contributing and inhibiting factors of MCLC performance in legalizing and executing budget, and to propose the alternative performance model of MCLC performance in legalizing and executing budget. 


\section{Discussion \\ Mechanism of Legal Drafting, Legalizing and Executing Local Council Budget}

In good governance perspective, there three main actors, namely: state, civil society and private/corporate in which they have to have synergetic networking (Widodo, 2001: 20-23). If this perspective is about to be related to the mechanism of legal drafting, legalizing and executing local budget, each actor will play different role(s). The state (local government and local council) plays the drafting and legalizing roles. Civil society as the beneficiary of budgeting policy plays the controlling and feeding back roles. While the private/corporate plays the executing role. Conceptually, in order to establish good governance, each actor with their role(s) has to play the role(s) in synergetic networking. But empirically, MCLC does not directly involve both civil society and private in local budgetary mechanism. Formally, there were never any involvement of both civil society and private in any local budgetary discussion forum. Thus, the fact shows that, informally, the internal of MCLC often had bargaining relationship and mutual agreement with both civil society and private before the local budget was drafted. This indirect involvement of civil society and private with MCLC either in bargaining relationship or mutual agreement had created rent-seeking behavior in local budgetary mechanism in Makassar City. The direct involvement of civil society and private, so far, can be seen when local council activity program was conducted.

The result shows that MCLC did not make any budgetary work plan in 2009 for the basis of local budgetary drafting of the 2010 budgetary year. The 2010 local budgetary drafting was done based on 2009 local budgetary draft. This was not right since the annual local budgetary should be based on the local dynamics and not based on the previous year draft. The local dynamics are accommodated in the work plan. So, regulatively, MCLC should have made budgetary work plan for the incoming budgetary year. Beside that, MCLC leader did not involve directly in budgetary drafting. The budgetary drafting was dominated by local council secretary and executive without having any consideration on people aspiration. This made the local direct expenditure, e.g. procurement of local goods, services and asset, irrational and only based on individual group interests. Down (1996) said that the bureaucrats in conducting public action are motivated mostly by their personal interests and political elites. It is true since the result of this research shows the same trend. The local executives and local political elites in Makassar City as the policy agent had been isolated in the rulling political party's interests.

\section{Performance Accountability of MCLC in Legalizing and Executing Local Budget in Good Governance Perspective}

According to the accountibility concept from Lembaga Administrasi Negara (2000), Fredrickson (2003), and Manggaukang (2006), it is a mandatory task for the government to publish to people what the government has done, how much the government spends the budget and how the outcome is. Related to good governance perspective, accountability performance of financial arrangement performed by MCLC can be described as follow. MCLC has a mandatory task to publish the accountability report of the local budget both internally and externally. Internally, MCLC has to deliver accountability report annually to authority holder over any utilization of financial resources regarding the financial arrangement regulation. Externally, MCLC has to inform the people or at least provide particular proper media to access annual accountability report. This is politically and morally as of MCLC accountability performance which is stated in Paragraph (g) of Article 45 of Law No. 32/2004 and in Paragraph (k) of Article 84 of Law No. 27/2009. The result shows that MCLC did not conduct its role as it is. MCLC did not deliver the external accountability report as well as not involve civil society and private sector in local budgeting mechanism. MCLC has a strategic position with particular strategic roles and by possessing this comes great accountability toward the people they represent. Ethically, every local council member is not permitted to disrespect people trust which has been mandated to them since the people are their constituents. That is why, local council position is not merely as political position, but it is more as an ethical position (Salang, 2009: 205). Prior to that, it is a must to be accountable over the local financial arrangement to the public based on the good regional budgetary principles which is accountable. Accountability here means that MCLC should be highly responsible in managing and spending public money (Sirajuddin, 2009: 60). It is also said that local council is accountable when they are capable of answering every kind of action and policy to the authority holder in which it is originated (Widodo, 2001: 306).

\section{Performance Transparency of MCLC in Legalizing and Executing Local Budget in Good Governance Perspective}

Performance tranparency in legalizing and executing local budget has been one of mandatory tasks for each local council institution including MCLC. It can be done by broadening the information access through public media involvement. Related to good governance perspective, performance transparency of MCLC should be initially performed by delivering local budget draft to public. In one hand, public will play their role as assessor, criticus, and feedback initiator toward the local budget publicly published. In another hand, private will serve implementor role by working on any budgetary programs. But in contrary, the result shows that the good 
governance principles are not performed well yet. The MCLC did not play their role, e.g. deliver local budget draft information to public only partly, the information published was not fully accessible, and there were not a specific public media to access the information on local budgeting. Thus, this made the public (community) cannot play their role. They cannot assess, criticize, and give any feedback for not having adequate information on local budgeting. Another governance actor, which is private, only played their indirect role when local budget had been legalized by working on particular programs.

These findings are similar to another finding of the research done by Soekarwo (2008). Soekarwo (2008) said that in legalizing and executing local budget, both politicians and bureaucrats were not transparent as well as not accountable to public. The mechanism of legal drafting, discussing, legalizing and executing local budget did not involve public (community). As the representation of public, local council should be transparent. They should broaden the access of information on local budgeting in every step of local budgetary process. This is the form of their responsibility to public which comply the basic principles of good local budgeting (Riswanda in Sirajuddin, 2009: 133).

\section{Performance Responsiveness of MCLC in Legalizing and Executing Local Budget in Good Governance Perspective}

Widodo (2001: 107) argued that local council as a representative institution in taking public action, attitude and policy have to stand for local problem, local need, local demand, and local aspiration of the society or people represented. They are forbidden to stand for their personal or group interest (s). Responsiveness in local budgeting context, is related to responsibility toward the service beneficiaries. Responsibility here means how far the local council reacts and responds on local local problem, local need, local demand, and local aspiration of their constituents or people they are represented (Widodo, 2001: 306).

In good governance perspective toward local budgeting mechanism, each of governance actors also has their own specific role(s). Local council should be able to skim, select, accommodate, and follow-up any assessment, demand and aspiration of the people on local budgeting. People are obliged to give feedback in the form of assessment, demand, and aspiration towards the local budget. The private are substantially performed the role as working partner in any budgetary program specified before. In order to perform this, local council should provide a proper medium for public to summit their assessment, demand and aspiration and respond to any local budget revision probability by changing the local budget draft before it goes to the next step.

The result shows that MCLC performance responsiveness in legalizing and executing local budget is not sufficient. This can be seen from several things as follow: MCLC did not provide any particular medium widely for public to skim, select, accommodate, and follow-up any assessment, demand and aspiration. The media can only be found in MCLC office building, MCLC members are less responsive in addressing any demand or aspiration of the people toward local budget, and likewise unserious attitude of MCLC members in addressing demand or aspiration of people which was then ended by the obligation to revise local budget during the running budgetary year of 2010. The result of this research is in reciprocal with the point of view of Dryzele (1996) in the journal namely Accountbudget planedility and Transparency in the West Virginia Budget Process (2010: 9) which emphasizes mechanism of budget formulating process through a long procees and almost free from supervising and public influence, not transparent, responsive, and productive. The impact is exploitation of budget source tends to be beneficial for legislative and executive and avoid public interest.

\section{Performance Effectiveness and Efficiency of MCLC in Legalizing and Executing Local Budget in Good Governance Perspective}

People demand to conduct reform on public bureaucracy performance including in local council institution has become public discourse today. Besides that, the merrier democratization issue has strengthen civil society to claim their rights when it is related to the bureaucracy, including their representative rights held by local council members (Agus Dwiyanto (2005: 135). Lenvine (1990: 188) stated that public service performance effectiveness can be assessed by expressing a few indicators such as: efficient, effectiveness, responsiveness, responsibility and accountable. Related to good governance perspective, effectiveness and efficiency of local budget should be as follow: local council draft, legalize, and execute local budget according to administrative procedure and legal budgeting mechanism; people (civil society) push and accelerate the government activity program implementation and give input through assessment, demand and aspiration; and privates involve in activity program implementation.

The research finding shows that the performance effectiveness and efficiency of MCLC in legalizing and executing local budget in budgetary year of 2010 did not adequate. Yet, it can be witnessed in few tendencies such as: (1) local budget drafting did not meet the budgetary principle based on the performance and not follow Permendagri N0.29/2002 on performance-basis budget, (2) drafting, executing and legalizing mechanism of Makassar City local budget in 2010 was not based on budgetary work plan. It was drafted based on the previous year budget and made up based on the prevailed estimation and price. MCLC functionaries also 
did not have any budget plan draft, (3) compared to Maros Regency and Gowa Regency, the utilization of MCLC local budget upon purchasing goods, service and capital were $347.81 \%$ and $483.95 \%$, (4) compared to Maros Regency and Gowa Regency, MCLC had bigger local council budget on $274.79 \%$ and $314.80 \%$, (5) MCLC legislation performance did not meet the target. Of 12 local regulations (Peraturan Daerah, Perda) which was planned to be legalized during 2010, only 6 Perda that was finally legalized (50\%). As well as budgetary performance, supervision performance of MCLC was also not effective.

This research result, in reciprocal with Ratih (2008: 186), complied that related to the legal drafting and executing process of local budget in Makassar City, MCLC can use its political power by distributing budget more easily and revising (cut and or add) local bedget portion. It can be used to profit particular party and be harmful to another party. The implication was that MCLC only tried to multiply program and budget. Moreover, Garamfalvi (1997) in Pratiwi (2010: 188) argued that politicians using their power to decide local budget and budget source allocation in order to get personal or group profit. In this case, politicians can exploit their power to gain rents or economical profit, through political manipulation over public policy which impacts source allocation in budgetary is not effective and efficient. There are some obstacles that needed to be faced in increasing local council performance internally such as: human resource, administrative management and recruitment process of local council members. Externally, local council performance can be increased by optimalized: economic motive and party interest, law and regulation, and fund limitation.

\section{Conclusion And Research Implication}

From theoretical discussion, research findings, and research result discussion above, this research attempts to express several conclusive notes and research implications as follow.

\section{Conclusion}

1. Procedure of legal drafting, legalizing and executing local council budget was not compiled based on 2009 working plan, but local council budget draft of 2010 budgetary year was based on the previous year budget, so the legalization based on estimation by adjusting the prevailed price. The MCLC budget upon procurement of goods, services and capital was irrational, if it is compared to Maros Regency and Gowa Regency local council budget;

2. Performance accountability, transparency, responsiveness, effectivity, and effieciency of MCLC in legalizing and executing local council budget in 2010 budgetary year did not adequate;

3. Internal factor which influences the performance of MCLC in legalizing and executing local council budget in 2010 such as human resources capability. Administration supervision and management of local council especially personel placement who serves in committees or budgetary committee did not adequate with the forte and the competence and local council member recruitment system. External factors which impact local council performance in legalizing and executing local council budget such as: economic motive and political interest, law regulation and fund limitation;

4. Procedure and mechanism which is proper to increase MCLC performance in legalizing and executing local council budget through society participation indirectly. People convey their assessment, demand, or aspiration through printed/electronic media. Besides that, people can convey their assessment, demand or aspiration directly to MCLC. Printed/electronic media conveys people aspiration to MCLC to be followed up. The follow up from MCLC is reconveyed through printed/electronic media to the society. The procedure and mechanism will run effectively and efficiently if it is supported through political approach, administration and management, law and fund limitation; and

5. Research result upon accountability, transparency, effectiveness and efficiency in legalizing and executing local council budget in good governance perspective does not yet run optimally. Government roles are more prominent, thus civil society and private do not have enough space to play their roles in the process and mechanism of legalizing and executing local council budget.

\section{Research Implication}

The research implication can be parted into theoretical and practical implication as mentioned below.

\section{Theoritical Implication}

The result shows that financial arrangement of MCLC has not applied financial management order principles according to the financial management order of Shafritz and Russel (1997) which reflects democratic, fair, and transparent principles which have high morale. MCLC financial management order especially procedure of legal drafting, legalizing and executing local council budget has not well based on governance theory of Ganie Rahman (2000) that in drafting, legalizing and executing state budget, the three governance pillars which are; state, civil society, and private/corporate should be all involved. 


\section{Practical Implication}

This research finding will bring implication to the competent parties involved in the process of drafting, legalizing and executing local budget as the following:

1. To MCLC, the process of legal drafting, legalizing and executing local budget, it is a must to involve society as a control tool so local council budget will be used properly based on budgetary principle which are rational, accountable, transparent, effective, and efficient;

2. In order to embody local council financial management order performance optimalization especially good governance principles application in legalizing and executing local council budget, the proper alternative development model through indirect participation model is needed. People convey assessment, demand, or aspiration through printed/electronic media. Besides that, people can convey assessment, demand, or aspiration directly to MCLC. The printed/electronic media convey people aspiration to MCLC to be followed-up. Follow up from MCLC will be reconveyed through printed/electronic media to the society. The procedure and mechanism will run effectively and efficiently if it is supported through political approach, administration and management and law. There are a few approaches to increase local council performance in legalizing and executing MCLC budget namely political approach, law and administration/management through:

1) Political approach

a. Public policy resulted is the embodiment and will of the people and beneficial for the increase of people prosperity and public service; and

b. The integrity of local council members is reflected from the attitude and their behaviours in prioritizing public interest.

2) Administrative and Management Approach

a. The existence of clear and firm procedure of operational guidance and expression mechanism of people aspiration to the printed/electronic media in the form of local council decision related to local council order;

b. The existence of operational guidance on budget plane and financial resource and function and role of printed/electronic media in the form of local council decision related to local council order; and

c. The existence of clear and firm operational guidance is needed on local council responsibility in responding to society aspiration through printed/electronic media and follow-up media in the form of local council decision related to local council order.

3) Law Approach

a. It is needed to be followed-up by law regulation which is binding and law sanction if local council is not embodied people aspiration;

b. It is needed to be followed-up with local council decision on order which manages function and role of printed/electronic media and its remuneration in the form of binding regulation and legally enforced;

c. It is needed to revise Law No.32/2004 on Local Government especially Article 45 Paragraph (e) and (g) which regulate local council responsibility in responding people aspiration and accountability of local council members morally and politically by more emphasizing the bonding legal aspect and sanction as the punishment; and

d. It is needed to revise Law No.10/2008 on Legislative, Regional Representative and Local Council General Election and to revise Supreme Court Decision of 2009 on Legislative, Regional Representative and Local Council General Election based on the most votes.

\section{bibliography}

[1]. Amal, Ichlasul. 1997. Fungsi Perwakilan, Pembuatan keputusan dan Pembentukanlegitimasi. Modul Pendalaman Bidang Tugas LOCAL COUNCIL TK.I dan TK.II Badan Pendidikan dan Pelatihan Departemen Dalam negeri.

[2]. Antoft, K. \& Novack, J. 1998, Grassroots Democracy : Local Government in theMaritimes, Nova Scotia: Henson College. Dalhousie University.

[3]. Development Bank, (1999), Governance : Sound Development Management.

[4]. Bacal, Robert. 1999. Ferformance Management. New York: The McGraw-Hill Companies, Inc.

[5]. Badan Pengawas Keuangan dan Pembangunan.1995 : Petunjuk tehnis Pemeriksaan Kompregenship Terhadap Instansi Pemerintah , Standar Tindak lanjut dan Standard Laporan Audit (APFP).

[6]. Bryant, Caroline \& White Louise.1987.Manajemen Pembangunan untuk Negara Berkemban. LP3ES.Jakarta.

[7]. Chandler, Ralph C \& Plano Jack C. 1982. The Public Administration Dictionary. Jonhn Wiley \& Sons. New York Brisbane. Toronto.Singapura.

[8]. Darwin, Muhadjir. 1996. Dalam Demokrasi Indonesia Kontenporer, PT. Raja Grafindo Persada, Jakarta.

[9]. Denhardt, J.V. and R.B. Denhardt. 2003. The New Public Service: Serving Not Steering.Expanded Edition. New York M.E. Sharpe.

[10]. Dryzek, Johnson. 1995. Political Inclution and Dinamyc : American Political Science Review. Vol.90 No.1.

[11]. Dwiyanto, Agus. 2002. Reformasi Birokrasi Publik di Indonesia. Gajah Mada University Press.Jogyakarta.

[12]. Dwiyanto, Agus. 2005. Penilaian Kinerja Organisasi Pelayanan Publik.Seminar Kinerja Organisasi Sektor Publik, kebijakan dan Penerapannya, Jurusan Ilmu Administrasi negaraFakultas Ilmu Sosial dan Ilmu Politik UGM. Yogyakarta.

[13]. Effendi, Sofian. 1991. Membangun Kapasitas AdministrasiUntuk Pelaksanaan Otonomi Daerah.Volume 3. Jakarta. 
[14]. Faisal, Sanafiah. 1990. Penelitian Kualitatif, Dasar-Dasar Aplikasi, Yayasan Asih Asuh. Malang.

[15]. Frederickson, H. George. 1988. Administrasi Negara-Negara Baru. LP3ES. Jakarta.

[16]. __ _ 2003. The Public Administration Thery Primer.University Of Nerbraska.Westview Press, A Member Of The Perseus Books Group.

[17]. Gaffar, Affan. 1997. Kekuatan-kekuatan Politik Kontenporer di Indonesia, Media Massa dan LOCAL COUNCIL . Modul Orientasi Pendalaman Bidang Tugas LOCAL COUNCIL TK.I dan II, Badan Pendidikan dan Latihan, Dep. Dalam negeri, Jakarta.

[18]. ___2000. Beberapa Salah Paham Tentang Kebijaksanaan Otonomi Daerah di Indonesia (Bahan Kuliah) pada Program Magister Ilmu Administrasi, Program Pasca Sarajana Univ. 17 Agustus Subudget planedaya.

[19]. Gomes, Faustino Cardoso.1995 Manajemen Sumber Daya manusia. Andi Offse . Jogyakarta.

[20]. Hanafi, Iman dan Nugroho Tri Laksono. 2009. Kebijakan keuangan Daerah : Reformasi dan Model Pengelolaan keuangan Daerah di Indonesia. Universitas Brawijaya Press. Malang.

[21]. Handoko, T. Hani. 2001, Manajemen Personalia dan Sumber Daya Manusia. Edisi 2 BPFE. Yogyakarta.

[22]. Haris, Syamsuddin. 2007. Desentralisasi dan Otonomi Daerah. Cetakan ke 3. LIPI Press. Jakarta.

[23]. Hoessein, B. 2002. Kebijakan Desentralisasi : Jurnal Administrasi Vol.1 No.1.Mei.

[24]. Huges, Owen E. 1994. Public Management and Administration. 2nd Ed.London: MacMillan Press Ltd

[25]. .Imawan, Riswanda. 1997, Membeda Politik Orde Baru. Pustaka Pelajar. Yogyakarta.

[26]. __ _. 2007. Bunga Rampai Desentralisasi dan Otonomi Daerah. LIPI Press. jakarta.

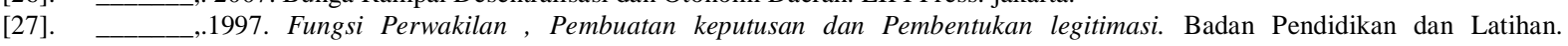
Departemen Dalam Negeri Jakarta.

[28]. Islamy, Irfan. 2000. Kebijakan Publik dan Kepentingan Daerah, Modul Pendalaman Bidang Tugas Anggota LOCAL COUNCIL . Fakultas Ilmu Administrasi Universitas Brawijaya.Malang.

[29]. ___..1998, Agenda Reformasi Administrasi Negara, Pidato Pengukuhan Guru besar Dalam Ilmu Kebijakan Publik pada Fak.Ilmu Administrasi ,Univ.Brawijaya Malang.

[30]. Jbudget planedra , J.G \& Dwivedi, O.P. 1989. Public Service Accountbudget planedility. Inc, Connecticut: Kumarian Press.

[31]. Kumorotomo, Wahyudi. 1996. Meningkatkan Kinerja BUMN: Antisipasi Terhadap Kompetisi dan kebijakan Deregulasi. JKAP.No.1. Yogyakarta.

[32]. Lembaga Administrasi negara (LAN-RI) 2004 : Modul Sistem Akuntbudget planedilitas Kinerja

[33]. Instansi Pemerintah. Edisi kedua. LAN-RI. Jakarta.

[34]. Lembaga Administrasi negara (LAN;RI) 2000, Pedoman Pelaporan Kinerja Instansi Pemerintah. LANRI. Jakarta

[35]. Lembaga Administrasi Negara (LAN-RI).1999. Pengukuran Kinerja Instansi Pemerintah. Lembaga Administrasi Negara dan Badan Pemeriksa Keuangan.Jakarta. LAN-RI, Jakarta.

[36]. Lenvine, CH., B.G. Peters dan F.J Thompson, 1990. Public Administration Challenges, Choice, Consequencies. Scott, Foresman, Illinois.

[37]. Lincoln, Yvona S. \& Egon G. Guba. 1985 , Naturalistic Inquiry. Beverly Hills.Sage Publications.

[38]. Maggaukang .2006 .Akuntbudget planedilitas Pemerintahan Lokal Dalam Otonomi Daerah: Studi Kasus Pemerintah Daerah Nusa Tenggara Barat (Ringkasan Disertasi). Universitas Brawijaya Malang.

[39]. Mahmudi, 2007. Manajemen Kinerja Sektor Publik. Akademi Manajemen Perusahaan YKPN, Yogyakarta

[40]. .Mahsun, Muhammad. 2009. Pengukuran Kinerja Sektor Publik. BPFE. Jogyakarta.

[41]. Muhammad. 2006. Pengaruh Kinerja Setelah Publik. Edisi Pertama. Penerbit BPFE. Yogyakarta.

[42]. Mangkunegara, Anwar Pbudget planedu. 2009. Evaluasi Kinerja Sumber Daya Manusia. Cetakan Kedua. PT. Refikta Arditama. Yoyakarta.

[43]. Mardiasmo. 2002. Otonomi dan manajemen Keuangan Daerah. Andi .Yogyakarta.

[44]. ___.1999. Reformasi Pengelolaan Keuangan Daerah: Implementasi Value for Money Audit Sebagai Antisipasi Terhadap Tuntutan Akuntbudget planedilitasPublik, Jurnal Akutansi \& Auditing Indonesia. Vol.4.

[45]. Meuthia, Ganie Rochman 2000. Good Governance : Prinsip, Komponen dan Penerapannya Dalam Ham . Bapenas .Jakarta.

[46]. Miles, Matthew B. Huberman Michael. 2007. Analisa Data Kualitatif. Diterjemahkan oleh Cecep Rohende Rohidi. UI-Press

[47]. Moleong, Lexy J. 2002. Metodologi Penelitian Kualitatif. Remaja Rosda Karya. Bandung.

[48]. Muluk Khairul, M R. 2009. Peta Konsep Desentralisasi dan Pemerintahan Daerah, ITS Press. Subudget planedaya.

[49]. ㄴ. 2007. Desentralisasi \& Pemerintahan Daerah. Bayu Media. Malang. 